\title{
Archaeological Testing of Site 41HK28 Haskell County, Texas
}

Wayne C. Young

Follow this and additional works at: https://scholarworks.sfasu.edu/ita

Part of the American Material Culture Commons, Archaeological Anthropology Commons, Environmental Studies Commons, Other American Studies Commons, Other Arts and Humanities Commons, Other History of Art, Architecture, and Archaeology Commons, and the United States History Commons

Tell us how this article helped you.

This Article is brought to you for free and open access by the Center for Regional Heritage Research at SFA ScholarWorks. It has been accepted for inclusion in Index of Texas Archaeology: Open Access Gray Literature from the Lone Star State by an authorized editor of SFA ScholarWorks. For more information, please contact cdsscholarworks@sfasu.edu. 


\section{Archaeological Testing of Site 41HK28 Haskell County, Texas}

\section{Licensing Statement}

This is a work produced for the Texas Department of Transportation (TxDOT) by the report producer. TxDOT and the report producer jointly own all rights, title, and interest in and to all intellectual property developed under TXDOT's contract with the report producer. The report may be cited and brief passages from this publication may be reproduced without permission provided that credit is given to both TxDOT and the report producer. Permission to reprint an entire chapter, section, figures or tables must be obtained in advance from either the Supervisor of the Archeological Studies Branch, Environmental Affairs Division, Texas Department of Transportation, 125 East 11th Street, Austin, Texas, 78701 or from the report producer. 
ARCHABOLOGICAL TESTING OF SITE 41HK28

HASKEL COUNTY, TEXAS

\author{
Wayne C. Young
}

Texas

State Department of Highways and Public Transportation Highway Design Division

August 1985 


\begin{abstract}
Testing of Site $41 \mathrm{HK} 28$ on County Road 166 in Haskell County, Texas, was performed on July 8-9, 1985, to determine eligibility for inclusion within the National Register of Historic Places or nomination as a State Archaeological Landmark, and to determine site depth, cultural context, and archaeological significance. The site is located on a terrace overlooking California Creek, a tributary of the Brazos River system. The site has been impacted by construction of a county road and bridge, by severe erosion and deflation, and by root plowing to remove mesquite trees from the area. Results of testing indicate that Site $41 \mathrm{HK} 28$ represented a Transitional Archaic site which has been largely destroyed by erosion and mesquite clearing. The site appears to be limited to the surface or upper $10 \mathrm{~cm}$ of the soil deposits and is mixed with modern historic debris. Evidence recovered does not support a determination of eligibility for inclusion within the National Register of Historic Places or nomination as a State Archaeological Landmark.
\end{abstract}




\section{INTRODUCTION}

Archaeological Site 41 HK 28 was recorded at the Texas Archeological Research Laboratory of the Balcones Research Center, The University of Texas at Austin, in May 1984 by a member of the State Department of Highways and Public Transportation (SDHPT) professional cultural resources staff. Following initial evaluation, further testing and investigation were recommended. The site was tested on July 8-9, 1985, by Wayne C. Young of the SDHPT professional cultural resources staff, with field support personnel provided by the SDHPT District 8 Residency Office in Hamlin, Texas.

Site 41HK28 is located in southeastern Haskell County about 14 miles southeast of Haskell (Fig. 1). The site is situated along County Road 166 about 0.5 mile east of Farm to Market Highway 600 and occupies a terrace along the western bank of California Creek. Site 41HK28 occurs along both sides of the county road and covers an area about 150 meters along the creek and 50 meters to the west of the creek bank.

Testing of the site was performed under the auspices of Procedures for the Protection of Historic and Cultural Properties (36 CFR, Part 800), procedures prescribed and endorsed by the Federal Highway Administration. The object of testing was to determine eligibility for inclusion of the site within the National Register of Historic Places or nomination as a State Archaeological Landmark as prescribed by federal regulation, and to determine the nature of the deposits and the cultural context of the site.

The construction affecting Site 41 HK 28 involves the replacement of a Warren truss bridge with a modern concrete structure and a reconstruction of the approaches for approximately $200 \mathrm{ft}$. West and $400 \mathrm{ft}$. east of the bridge. The county road will be closed, the old bridge dismantled, and a new structure erected in its place. Additional right-of-way has been obtained for $200 \mathrm{ft}$. east and $400 \mathrm{ft}$. West of the bridge and is a uniform $100 \mathrm{ft}$. in width. 
This Page Redacted Per THC Policy 


\section{SITE DESCRIPTION}

Site 41HK28 appears to have covered about an acre along the western bank of California Creek in Haskell County, Texas. The site is presently in a heavily overgrazed pasture with the dominant vegetation being small mesquites and broomweeds. It should be mentioned that the mesquite trees on the site are noticeably smaller than those in other pastures and that there are several brush piles present, indicating that the site has been cleared of trees in the relatively recent past. The site has probably been root-plowed within the last 20 years.

Erosion is severe on the site and may be partially attributed to the lack of ground cover in the immediate area. Very large and deep gullies are present along both sides of the county road and have cut through about $75 \%$ of the site within the right-of-way (Fig. 2). These gullies show a clean soil profile consisting of a reddish soil cap of clay loam for the upper $20 \mathrm{~cm}$. This soil cap overlies a 2 meter-thick zone of brownish red clay loam with precipitation lines and small calcium carbonate gravels. The lowest meter of the gully profiles is a very red clay lacking gravels. There are several cut and fill sequences observable in the gully walls and all cultural materials within the gullies were contained in these areas. The one complete dart point, a Darl-like specimen, was found on the surface about 2 meters from the edge of the north gully and is very similar to the dart point base found in Level 1 on the south side of the road.

The gully profiles appeared at first to have dark bands representing cultural zones in them. A closer examination revealed that these bands were caused by decaying tree roots and that they disappeared when only slightly excavated. 


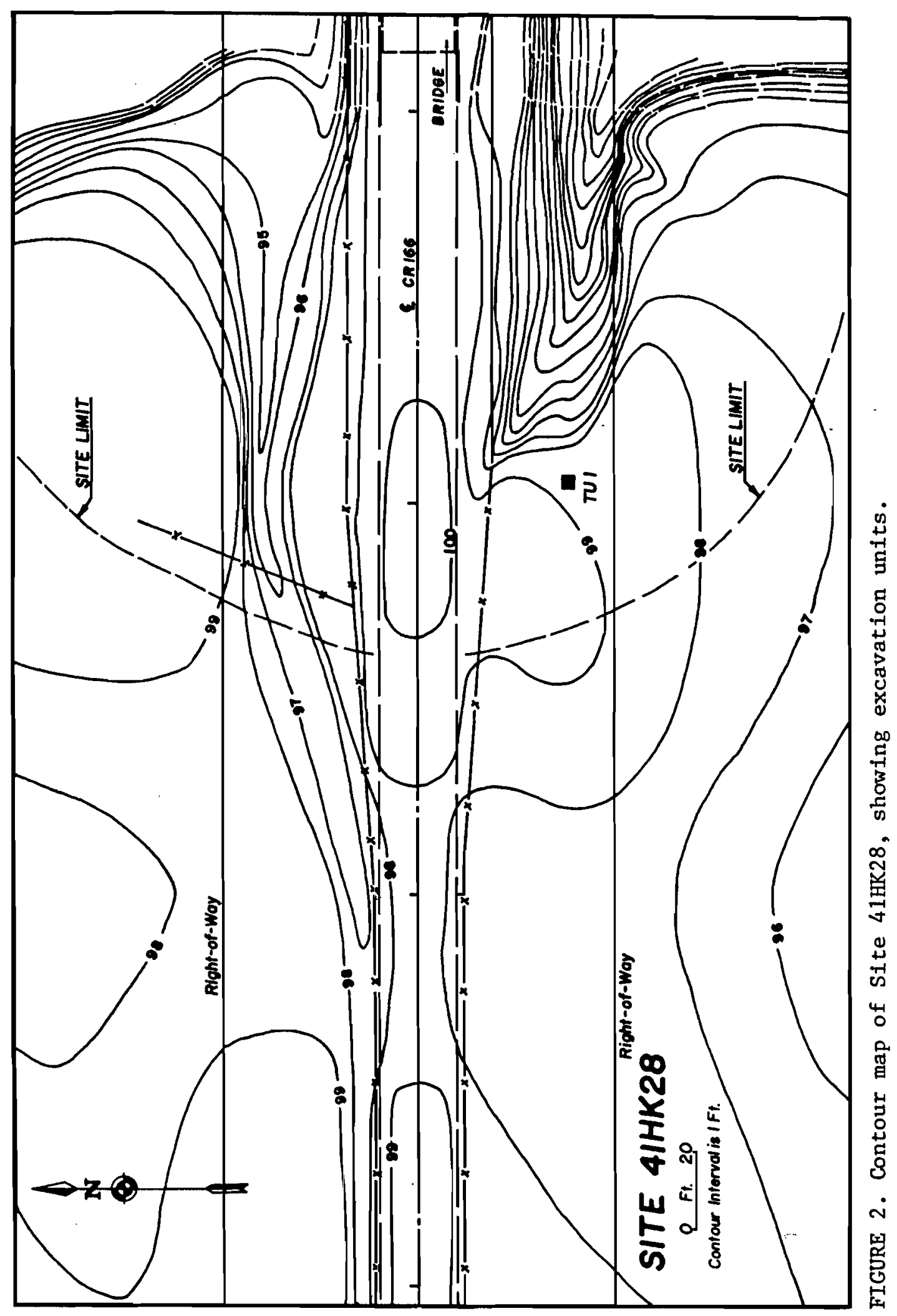


The gullies are still quite active at the site today, as witnessed by one of the larger mesquites having been undercut and lying in the gully. The leaves were still green on the tree and it may be presumed that the tree had only recently sloughed into the gully. 


\section{TESTING OPERATIONS}

Archaeological testing of Site $41 \mathrm{HK} 28$ consisted of surface observations, examination of gully walls, and the excavation of a test unit by hand (Fig. 2). A n examination of the ground surface revealed a thin scattering of flint and quartzite flakes and burned rocks along both sides of the county road. One possible surface hearth was located between the gully and Test Unit 1 on the south side of the road and was partially excavated. Excavation of this limestone hearth was halted when a rusted tin can was found in the center of the hearth. This feature may relate to the construction of the bridge across California Creek.

The examination of the gully was accomplished by a slow and thorough study of all visible profiles on both sides of the county road and the noting of all cultural debris adhering to the walls. This procedure failed to indicate any buried cultural zones although over 100 meters of profile were observed. A total of 3 flakes, a Darl-like dart point, and a thumbnail end scraper were recovered in this procedure, with all specimens coming from a cut and fill sequence in the north gully.

There were no surface concentrations of materials or any evidence of intact subsurface cultural zones; therefore, a locality adjacent to the historic surface-hearth at the head of the south gully was chosen for the placement of Test Unit 1. Test Unit 1 was a 1 meter square. Excavation was in arbitrary $10 \mathrm{~cm}$ levels with all soil passed through 0.25 in. mesh hardware cloth and all cultural material retained by square and level coordinates.

Level 1 contained a Darl-like dart point base, 3 core fragments, 2 mussel shell fragments, 26 flakes, 3 glass bottle sherds, and 5 fragments from tin cans. Levels 2-5 were culturally sterile. The excavations were halted at $50 \mathrm{~cm}$ since the previous $40 \mathrm{~cm}$ had been culturally sterile and there were no indications of deeper cultural zones from the gully walls.

A 11 of the cultural material was found to be in a disturbed context and limited to the top $10 \mathrm{~cm}$ of the site. 
Archaeological testing of Site $41 \mathrm{HK} 28$ has established that the site was primarily a surface occupation that can be related to the Transitional Archaic and that the site has been disturbed by past agricultural and construction activities--specifically overgrazing, root plowing, and the construction of the road and bridge.

The portions of the site within the right-of-way lack a valid cultural context and the same probably holds for the area outside the right-ofway. Cultural remains appear to have been severely eroded and disturbed. It is believed that the portion of Site 41HK28 within the highway rightof-way does not meet the criteria for inclusion within the National Register of Historic Places or for State Archaeological Landmark status. No further investigation of Site $41 \mathrm{HK} 28$ is recommended. 